\title{
DESKRIPSI KEMAMPUAN PEMECAHAN MASALAH MATEMATIS SISWA KELAS VIII MTSN KOTA PALOPO BERDASARKAN GENDER
}

\author{
Fahrul Basir ${ }^{1}$, Nur Fadillah Wahdaniya ${ }^{2}$ \\ Universitas Cokroaminoto Palopo ${ }^{1,2}$ \\ fahrulb@uncp.ac.id ${ }^{1}$
}

\begin{abstract}
Abstrak
Penelitian ini adalah penelitian deskriptif kualitatif yang bertujuan untuk mendeskripsikan kemampuan pemecahan masalah matematis siswa MTs Negeri Kota Palopo Berdasarkan Gendernya. Masalah dalam penelitian ini adalah kemampuan pemecahan masalah matematis siswa yang masih belum optimal. Subjek dalam penelitian ini adalah siswa kelas VIII C MTs Negeri Kota Palopo yang berjumlahkan 2 orang, yaitu 1 subjek laki-laki dan 1 subjek perempuan. Instrumen penelitian yang digunakan adalah peneliti itu sendiri. Pengumpulan data dilakukan dengan tes tertulis dan dilanjutkan dengan wawancara secara individual untuk memperoleh data yang valid. Hasil penelitian menunjukkan kemampuan pemecahan masalah matematis kedua subjek dalam menyelesaikan tes yang diberikan seseuai indikator pemecahan masalah yaitu: (1) Memahami masalah (2) Merencanakan penyelesaian masalah. (3) Menyelesaiakan masalah melalui strategi pemecahan masalah (4) Serta memeriksa kembali hasil dan proses dan menyimpulkan hasil penyelesaian.
\end{abstract}

Kata kunci: Kemampuan pemecahan masalah matematis, berdasarkan gender

\section{A. Pendahuluan}

Kemampuan pemecahan masalah dalam matematika merupakan hal penting yang perlu dikuasai oleh peserta didik. Hal tersebut sejalan dengan prinsip-prinsip dan standar matematika sekolah dari National Council of Teacher Mathematics (NCTM, 2000), menetapkan lima standar kemampuan matematis yang harus dimiliki peserta didik, salah satunya adalah kemampuan pemecahan masalah (problem solving). Kemampuan pemecahan masalah matematis merupakan kemampuan peserta didik dalam mencari solusi dalam mencapai tujuan, serta mengaplikasikannya dalam menyelesaikan permasalahan sehari-hari.

Seorang peserta didik dikatakan mampu menyelesaikan masalah matematis apabila mereka dapat memahami masalah, memilih strategi yang tepat serta dapat menerapkannya dalam penyelesaian masalah. Kemampuan pemecahan masalah sangat 
berpengaruh terhadap hasil belajar matematika peserta didik, karena kemampuan pemecahan masalah matematis dapat membantu memecahkan persoalan baik dalam pelajaran maupun kehidupan sehari-hari. Namun, kenyataannya di Indonesia kemampuan tersebut masih kurang dan perlu ditingkatkan lagi.

Manusia diciptakan menjadi dua jenis yaitu perempuan dan laki-laki yang menjadi dasar pembeda identitas manusia, secara fisik, kemampuan matematika, keunggulan, kelemahan, serta kemampuan sosialnya. Namun bukan berarti perempuan lebih unggul ataupun sebaliknya. Selama ini perbedaan jenis kelamin tersebut sebagai salah satu yang membedakan perkembangan kognitif manusia yang tentu saja sangat mempengaruhi bagaimana kemapuan berfikir seseorang.

Witelson menyatakan bahwa dalam gaya berfikir perempuan berbeda dari lakilaki karena ukuran dan bentuk otak yang berbeda dimana otak peempuan secara keseluruhan jauh lebih kecil dari otak laki-laki. Kartono menyatakan disbanding lakilaki umumnya perempuan jauh lebih akurat dan mendetail dalam memperhatikan sesuatu. Dengan berpendapat kemampuan verbal anak perempuan jauh lebih tinggi dari anak laki-laki.

Gender juga merupakan karakteristik yang membedakan peserta didik perempuan dan laki-laki dalam belajar khusunya dalam pembelajaran matematika. Gender merupakan atribut yang diasosiasikan dengan jenis kelamin seseorang termasuk peran, tingkah laku, preferensi yang menerangkan kelaki-lakian atau kewatiaan dalam konteks budaya tertentu (Hoang, 2008). Perbedaan gender dalam belajar matematika dapat menjadi faktor pembeda seseorang berfikir dan menentukan pemecahan masalah yang diambil contohnya dalam dunia pendidikan yang memainkan peran bagi kehidupan peserta didik. Ketika dihadapkan pada soal yang bersifat pemecahan masalah, peserta didik laki-laki dan peserta didik perempuan memiliki cara tersendiri atau cara yang berbeda dalam memecahkan masalah. Niederle \& Vesterlund (Wulandari, 2016) menyebutkan peserta didik perempuan memiliki gaya belajar yang bebas dibanding siswa laki-laki. Perbedaan itulah yang mendasari pola belajar peserta didik perempuan yang lebih bervariasi sehingga memungkinkan adanya kolaborasi atau kerja sama dan interaksi di dalam kelas. Sedangkan peserta didik laki-laki lebih 
cenderung menyukai proses pembelajaran bersifat individual dan lebih menyenangi kompetisi.

Bonolken (2014) menyebutkan bahwa peserta didik laki-laki yang tidak berbakat menunjukkan fungsional matematika lebih baik dibandingkan peserta didik perempuan. Hal tersebut bermakna bahwa peserta didik laki-laki yang memiliki keterbatasan berpikir matematis lebih mampu menggunakan berbagai atribut matematika ke dalam pemecahan masalah dibandingkan peserta didik perempuan.

\section{B. Metode Penelitian}

Jenis penelitian adalah penelitian deskriptif dengan pendekatan kualitatif. Penelitian ini dilaksanakan di kelas VIII Mts. Negeri Kota Palopo, Jl. Andi Kambo, Surutanga, Kec. Wara Timur, Kota Palopo, Provinsi Sulawesi Selatan. Penelitian ini dilaksanakan pada semester ganjil tahun ajaran 2020/2021.

Fokus penelitian ini adalah mendeskripsikan kemampuan pemecahan masalah siswa kelas VIII Mts. Negeri Kota Palopo berdasarkan gender yang didasarkan pada indikator pemecahan masalah yang terdiri dari memahami masalah, merencanakan penyelesaian masalah, melakukan rencana penyelesaian, dan melihat kembali.

Instrumen penelitian adalah peneliti sendiri. Pada penelitian ini juga digunakan instrumen pendukung lainnya yaitu : (1) tes pemilihan subjek penelitian, (2) pedoman wawancara.

Keabsahan data merupakan konsep penting dalam penelitian kualitatif. Pemeriksaan terhadap keabsahan data bertujuan untuk mengurangi bias yang terjadi pada saat pengumpulan data. Sugiyono (2006:302) mengatakan bahwa keabsahan data dalam penelitian kualitatif meliputi uji kredibilitas, uji transferabilitas, uji dependabilitas, dan uji konfirmabilitas.

Analisis data kualitatif merupakan proses berkelanjutan yang membutuhkan refleksi terus-menerus terhadap data, mengajukan pertanyaan-pertanyaan analisis dan menulis catatan singkat sepanjang penelitian (Creswell, 2012). Data yang telah dikumpulkan akan dianalisis dengan menggunakan analisis data nonstatistik karena penelitian ini merupakan penelitian kualitatif. Analisis dilakukan secara mendalam 
pada siswa tentang pemecahan masalah setelah siswa dikategorikan berdasarkan gendernya. Proses analisis data dimulai dengan menelaah seluruh data yang tersedia dari berbagai sumber, yaitu dari wawancara pengamatan yang sudah dituliskan dalam catatan lapangan, dokumen pribadi, dokumen resmi, gambar, foto, dan sebagainya (Moleong, 2011). Analisis data dilakukan terbatas pada apa yang dikerjakan siswa (baik secara lisan maupun tulisan). Langkah-langkah menganalisis data sebagai berikut:

1. Menelaah seluruh data yang tersedia dari berbagai sumber, yaitu dari wawancara, pengamatan yang sudah dituliskan dalam catatan lapangan dan hasil tes pemecahan masalah.

2. Reduksi data adalah kegiatan yang mengacu pada proses menyeleksi, memfokuskan, mengabstraksikan, dan mentransformasikan data mentah. Dalam penelitian ini dilakukan dengan membuat rangkuman yang terdiri dari inti, proses, pernyataan-pernyataan yang sesuai dengan tujuan penelitian. Kata-kata subjek yang tidak sesuai dengan tujuan penelitian dihilangkan. Validasi data dilakukan pada saat pengumpulan data berlangsung, yaitu dengan cara verifikasi.

3. Penyajian data yang meliputi pengklasifikasian dan identitas data, yaitu menuliskan kumpulan data yang terorganisir dan terkategori sehingga memungkinkan untuk menarik kesimpulan dari data tersebut. Dalam penelitian ini, data hasil wawancara tentang pemecahan masalah yang direduksi dikategorikan berdasarkan indikator pada setiap aspek yang diamati.

4. Membuat coding atau kode yang bertujuan untuk memudahkan pemaparan data analisis kemampuan pemecahan masalah siswa, maka dilakukan coding pada petikan jawaban subjek penelitian saat wawancara.

5. Memaparkan hasil wawancara dari hasil tes pemecahan masalah tentang kemampuan pemecahan masalah siswa.

6. Menafsirkan data/menarik kesimpulan penelitian dari data yang sudah dikumpulkan dan memverifikasi kesimpulan tersebut. Penarikan kesimpulan dilakukan berdasarkan analisis terhadap data yang telah dikumpulkan baik melalui tes, maupun wawancara terhadap subjek. Hal ini dilakukan dengan cara 
membandingkan hasil pekerjaan subjek dengan hasil wawancara sehingga dapat ditarik kesimpulan yang benar tentang pemecahan masalah yang dimiliki oleh siswa.

\section{Hasil Penelitian dan Pembahasan}

Hasil penelitian berupa deskripsi pemecahan masalah soal bangun datar berdasarkan gender. Deskripsi pemecahan masalah soal bangun datar berdasarkan gender dengan melihat indikator pada pemecahan masalah yaitu: (1) memahami masalah, (2) merencanakan masalah, (3) melaksanakan masalah, (4) melihat kembali.

Uraian ini berupa kata-kata, tulisan maupun respon subjek saat wawancara dalam pemecahan masalah soal bangun datar berdasarkan gender. Adapun masalah yang digunakan dalam penelitian ini adalah masalah mengenai bangun datar. Masalah tersebut disusun sesuai dengan perjenjangan indikator pemecahan masalah meliputi: memahami masalah, merencanakan masalah, melakukan rencana pemecahan, dan melihat kembali. Untuk mengidentifikasi pemecahan masalah pada setiap subjek, peneliti berupaya untuk mengetahui metode yang digunakan subjek dalam menyelesaikan masalah tersebut melalui deskripsi yang dilakukan peneliti.

Berdasarkan respon kedua subjek pada paparan hasil penelitian tersebut bahwa Subjek Berkemampuan Tinggi Gender Perempuan (SKTGP) dan Subjek Berkemampuan Tinggi Gender Laki-laki (SKTGL) mampu mencapai indikator memahami masalah hingga melihat kembali yang membedakan kedua subjek adalah cara kerja dalam menyelesaikan soal dan hasil akhir pada soal nomor 2, yang didapat kedua subjek pun berbeda. Respon subjek dalam menyelesaikan soal bangun datar berdasarkan indikator pemecahan masalah.

Langkah awal dalam penelitian ini adalah melakukan tes pemecaan masalah berupa essay sebanyak 3 nomor. Dalam memilih subjek penelitian, peneliti melihat hasil yang telah didapatkan dari tes pemecaan masalah yang diberikan, sehingga terpilihlah subjek yang berkemampuan tinggi gender perempuan (Rahmi) dan subjek yang berkemampuan tinggi gender laki-laki (Ahmad Khalik K.). Ada 3 butir soal essay yang mewakili setiap indikator pemecahan masalah yakni memahami masalah, 
merencanakan masalah, melakukan rencana pemecahan, dan melihat kembali. Dalam pembahasan hasil penelitian ini akan menjelaskan secara rinci hasil penelitian berdasarkan indikator-indikator pemecahan masalah.

Kemampuan pemecahan masalah Subjek Kemampuan Tinggi Gender Perempuan (SKTGP) untuk soal pertama yaitu: pertama, subjek telah memahami masalah yang diberikan karena subjek menuliskan yang diketahui, ditanyakan dan penyelesaian dengan benar, subjek menggunakan rumus mencari luas persegi dan mendaptkan hasil jawaban yang benar. Artinya Subjek Kemampuan Tinggi Gender Perempuan (SKTGP) melaksanakan dengan tepat indikator pemecahan masalah yaitu memahami masalah yang berkaitan dengan aspek kemampuan awal yaitu Pemahaman diartikan sebagai kemampuan dalam memahami materi tertentu yang dipelajari. Peserta didik menjawab pertanyaan dengan kata-kata sendiri dan dengan memberi contoh baik prinsip maupun konsep. Kedua, Subjek Kemampuan Tinggi Gender Perempuan (SKTGP) dalam memiliki rencana pemecahan masalah sudah tepat karena subjek telah memahami masalah yang diberikan tersebut. Artinya Subjek Kemampuan Tinggi Gender Perempuan (SKTGP) telah melaksanakan dengan tepat indikator pemecahan masalah yaitu merencanakan pemecahan yang berkaitan dengan aspek kemampuan awal yaitu pengetahuan. Ketiga, Subjek Kemampuan Tinggi Gender Perempuan (SKTGP) terlebih dahulu membuat rumus agar lebih mudah dalam mengerjakan soal dan melaksanakan rencana pemecahan sampai selesai hasil akhir yang didapatkan sudah tepat. Artinya Subjek Kemampuan Tinggi Gender Perempuan (SKTGP) telah melaksanakan dengan tepat indikator pemecahan masalah yaitu melaksanakan rencana pemecahan yang berkaitan dengan aspek kemampuan awal yaitu penerapan. Keempat Subjek Kemampuan Tinggi Gender Perempuan (SKTGP) telah memehuni indikator keempat karena pada indikator memahami masalah, merencanakan pemecahan dan melakukan rencana pemecahan sudah terpenuhi. Artinya Subjek Kemampuan Tinggi Gender Perempuan (SKTGP) telah melaksanakan dengan tepat indikator pemecahan masalah yaitu melihat kembali yang berkaitan dengan aspek kemampuan pemecahan masalah matematis yaitu semua indikator . 
Kemampuan pemecahan masalah Subjek Kemampuan Tinggi Gender Perempuan (SKTGP) untuk soal nomor dua yaitu: pertama, subjek belum memahami masalah yang diberikan karena subjek menuliskan segitiga yang berada pada soal kedua yaitu segitiga siku-siku dengan melakukan identifikasi dari soal dengan menuliskan informasi yang ditemukan dari soal berupa yang diketahui dan ditanyakan dari soal tersebut, serta menjelaskan masalah dengan kalimat sendiri. Artinya Subjek Kemampuan Tinggi Gender Perempuan (SKTGP) belum melaksanakan dengan tepat indikator pemecahan masalah yaitu memahami masalah. Kedua, Subjek Kemampuan Tinggi Gender Perempuan (SKTGP) dalam memiliki rencana pemecahan masalah belum tepat karena subjek belum memahami masalah yang diberikan tersebut. Artinya Subjek Kemampuan Tinggi Gender Perempuan (SKTGP) belum melaksanakan dengan tepat indikator pemecahan masalah yaitu merencanakan pemecahan. Ketiga, Subjek Kemampuan Tinggi Gender Perempuan (SKTGP) subjek terlebih dahulu membuat rumus agar lebih mudah dalam mengerjakan soal dan melaksanakan rencana pemecahan sampai selesai tetapi pada soal yang nomor dua hasil akhir yang didapatkan kurang tepat. Artinya Subjek Kemampuan Tinggi Gender Perempuan (SKTGP) belum melaksanakan dengan tepat indikator pemecahan masalah yaitu melaksanakan rencana pemecahan. Keempat Subjek Kemampuan Tinggi Gender Perempuan (SKTGP) belum memehuni indikator keempat karena pada indikator memahami masalah, merencanakan pemecahan dan melakukan rencana pemecahan belum terpenuhi. Artinya Subjek Kemampuan Tinggi Gender Perempuan (SKTGP) belum melaksanakan dengan tepat indikator pemecahan masalah yaitu melihat kembali.

Kemampuan pemecahan masalah Subjek Kemampuan Tinggi Gender Perempuan (SKTGP) untuk soal nomor tiga yaitu: pertama, subjek memahami masalah dengan melakukan identifikasi dari soal dengan menuliskan informasi yang ditemukan dari soal berupa yang diketahui dan ditanyakan dari soal tersebut, serta menjelaskan masalah dengan kalimat sendiri. Artinya Subjek Kemampuan Tinggi Gender Perempuan (SKTGP) memenuhi indikator pemecahan masalah yaitu memahami masalah. Kedua, Subjek Kemampuan Tinggi Gender Perempuan (SKTGP) dalam menyelesaikan soal subjek memiliki rencana untuk menjawab soal tes pemecahan 
masalah tersebut, selanjutnya subjek menggunakan informasi yang diketahui untuk membuat informasi baru sehingga dapat mengambil kesimpulan cara.

untuk mendapatkan x ialah dengan menggunakan rumus keliling. Artinya Subjek Kemampuan Tinggi Gender Perempuan (SKTGP) memenuhi indikator pemecahan masalah yaitu merencanakan pemecahan. Ketiga, Subjek Kemampuan Tinggi Gender Perempuan (SKTGP) terlebih dahulu membuat rumus agar lebih mudah dalam mengerjakan soal lalu memasukkan semua yang diketahui kedalam rumus tersebut dan melaksanakan rencana pemecahan sampai selesai. Artinya Subjek Kemampuan Tinggi Gender Perempuan (SKTGP) melaksanakan indikator pemecahan masalah yaitu melaksanakan rencana. Keempat, Subjek Kemampuan Tinggi Gender Perempuan (SKTGP) mengecek kembali semua informasi yang diketahui dan ditanyakan serta cara penyelesaiannya dan menyimpulkan hasil yang didapat dari pertanyaan. Artinya Subjek Kemampuan Tinggi Gender Perempuan (SKTGP) melaksanakan indikator pemecahan masalah yaitu melihat kembali.

Kemampuan pemecahan masalah Subjek Kemampuan Tinggi Gender Lakilaki (SKTGL) untuk soal pertama yaitu: pertama, subjek telah memahami masalah yang diberikan karena subjek menuliskan yang diketahui, ditanyakan dan menngerjakan penyelesaian soal dengan benar, subjek menggunakan rumus mencari luas persegi dan mendapatkan hasil jawaban yang benar. Artinya Subjek Kemampuan Tinggi Gender Laki-laki (SKTGL) melaksanakan dengan tepat indikator pemecahan masalah yaitu memahami masalah. Kedua, Subjek Kemampuan Tinggi Gender Lakilaki (SKTGL) dalam memiliki rencana pemecahan masalah sudah tepat karena subjek telah memahami masalah yang diberikan tersebut. Artinya Subjek Kemampuan Tinggi Gender Laki-laki (SKTGL) telah melaksanakan dengan tepat indikator pemecahan masalah yaitu merencanakan pemecahan yang berkaitan dengan aspek kemampuan awal yaitu pengetahuan. Ketiga, Subjek Kemampuan Tinggi Gender Laki-laki (SKTGL) terlebih dahulu membuat rumus agar lebih mudah dalam mengerjakan soal dan melaksanakan rencana pemecahan sampai selesai hasil akhir yang didapatkan sudah tepat. Artinya Subjek Kemampuan Tinggi Gender Laki-laki (SKTGL) telah melaksanakan dengan tepat indikator pemecahan masalah yaitu melaksanakan rencana 
pemecahan Subjek Kemampuan Tinggi Gender Laki-laki (SKTGL). Keempat Subjek Kemampuan Tinggi Gender Laki-laki (SKTGL) telah memehuni indikator keempat karena pada indikator memahami masalah, merencanakan pemecahan dan melakukan rencana pemecahan sudah terpenuhi. Artinya Subjek Kemampuan Tinggi Gender Perempuan (SKTGP) telah melaksanakan dengan tepat indikator pemecahan masalah yaitu melihat kembali yang berkaitan dengan aspek kemampuan pemecahan masalah matematis yaitu semua indikator .

Kemampuan pemecahan masalah Subjek Kemampuan Tinggi Gender Lakilaki (SKTGL) untuk soal nomor dua yaitu: pertama, subjek memahami masalah dengan menuliskan informasi yang ditemukan dari soal berupa yang diketahui dan ditanyakan dari soal tersebut, serta menjelaskan masalah dengan kalimat sendiri, subjek juga mampu menganalisis setiap butir yang diketahui dari soal. Artinya Subjek Kemampuan Tinggi Gender Laki-laki (SKTGL) memenuhi indikator pemecahan masalah yaitu memahami masalah . Kedua, Subjek Kemampuan Tinggi Gender Lakilaki (SKTGL) subjek mengolah atau menyusun informasi dengan melihat apa yang diketahui dari soal. Artinya Subjek Kemampuan Tinggi Gender Laki-laki (SKTGL) memenuhi indikator pemecahan masalah yaitu merencanakan pemecahan masalah. Ketiga, Subjek Kemampuan Tinggi Gender Laki-laki (SKTGL) dalam proses penyelesaian yang dilakukan subjek menyusun kembali secara rinci apa yang diketahui, ditanyakan dan juga membuat cara penyelesaiannya, sehingga subjek dapat melaksanakan dengan baik dan menjawab soal tersebut sampai selesai. Artinya Subjek Kemampuan Tinggi Gender Laki-laki (SKTGL) melaksanakan indikator pemecahan masalah yaitu melaksanakan rencana. Keempat, Subjek Kemampuan Tinggi Gender Laki-laki (SKTGL) mengecek kembali semua informasi dan perhitungan yang telah dilakukan dan menyimpulkan hasil yang didapatkan dari pertanyaan yang diberikan. Artinya Subjek Kemampuan Tinggi Gender Laki-laki (SKTGL) melaksanakan indikator pemecahan masalah yaitu melihat kembali.

Kemampuan pemecahan masalah Subjek Kemampuan Tinggi Gender Lakilaki (SKTGL) untuk soal nomor tiga yaitu: pertama, subjek memahami masalah dengan melakukan identifikasi dari soal dengan menuliskan informasi yang ditemukan dari 
soal berupa yang diketahui dan ditanyakan dari soal tersebut, serta menjelaskan masalah dengan kalimat sendiri, subjek juga mampu menganalisis setiap butir yang diketahui dari soal. Artinya Subjek Kemampuan Tinggi Gender Laki-laki (SKTGL) memenuhi indikator pemecahan masalah yaitu memahami masalah. Kedua, Subjek Kemampuan Tinggi Gender Laki-laki (SKTGL) subjek mengolah atau menyusun informasi dengan melihat apa yang diketahui dari soal. Artinya Subjek Kemampuan Tinggi Gender Laki-laki (SKTGL) memenuhi indikator pemecahan masalah yaitu merencanakan pemecahan. Ketiga, Subjek Kemampuan Tinggi Gender Laki-laki (SKTGL) dalam proses penyelesaian yang dilakukan subjek menyusun kembali secara rinci apa yang diketahui, ditanyakan dan juga membuat cara penyelesaiannya, sehingga subjek dapat melaksanakan dengan baik dan menjawab soal tersebut sampai selesai. Artinya Subjek Kemampuan Tinggi Gender Laki-laki (SKTGL) melaksanakan indikator pemecahan masalah yaitu melaksanakan. Keempat, Subjek Kemampuan Tinggi Gender Laki-laki (SKTGL) mengecek kembali semua informasi dan perhitungan yang telah dilakukan dan menyimpulkan hasil yang didapatkan dari pertanyaan yang diberikan. Artinya Subjek Kemampuan Tinggi Gender Laki-laki (SKTGL) melaksanakan indikator pemecahan masalah.

Hasil penelitian untuk Subjek Kemampuan Tinggi Gender Perempuan (SKTGP) dan Subjek Kemampuan Tinggi Gender Laki-laki (SKTGL) untuk tes pemecahan masalah saat tes wawancara menunjukkan bahwa subjek SKTGP dan SKTGL memiliki kemampuan yang sama, tetapi pada soal nomor 2 Subjek Kemampuan Tinggi Gender Perempuan (SKTGP) memiliki jawaban yang kurang tepat sehingga subjek tidak memenuhi indikator yang ketiga yaitu melakukan rencana. Indikator ketiga sangatlah penting saat mengerjakan soal, hal ini sesuai dengan penjelasan dari Polya (Yosepa, 2001), ada empat langkah-langkah dalam memecahkan suatu masalah yaitu pertama mengerti terhadap masalah, kedua buatlah rencana untuk menyelesaikan masalah, ketiga cobalah atau jalankan rencana tersebut, dan yang keempat lihatlah kembali hasil yang telah diperoleh secara keseluruhan.

National Council of Teachers of Mathematics (2000) menyebutkan bahwa memecahkan masalah bukan saja merupakan suatu sasaran belajar matematika, tetapi 
sekaligus merupakan alat utama untuk melakukan belajar itu. Oleh karena itu, kemampuan pemecahan masalah menjadi fokus pembelajaran matematika disemua jenjang, dari sekolah dasar hingga perguruan tinggi. Lebih spesifik Sumarmo (2005: 21) mengartikan pemecahan masalah sebagai kegiatan menyelesaikan soal cerita, menyelesaikan soal yang tidak rutin, mengaplikasikan matematika dalam kehidupan sehari-hari atau keadaan lain, dan membuktikan, menciptakan atau menguji konjektur.

Berdasarkan pengertian yang dikemukakan sumarno tersebut, dalam pemecahan masalah matematika tampak adanya kegiatan pengembangan matematika (mathematical power) terhadap siswa. Sedangkan pemecahan masalah menurut Polya (dalam Yosepa, 2001), merupakan suatu cara belajar yang dianggap sangat efisien dalam usaha untuk mencapai tujuan pengajaran. Proses belajar melalui pemecahan masalah bertolak pandangan bahwa siswa sebagai subjek dan objek dalam belajar yang mempunyai kemampuan untuk memecahkan masalah mereka sehingga siswa termotivasi untuk belajar keras. Pemecahan masalah sebagai suatu usaha mencari jalan keluar dari suatu kesulitan guna mencapai suatu tujuan yang tidah begitu mudah segera dapat dicapai dan menggaris bawahi bahwa "untuk pemecahan masalah yang berhasil selalu disertakan upaya-upaya khusus yang dihubungkan dengan jenisjenis persoalan sendiri serta pertimbangan-pertimbangan mengenai isi yang dimaksud". Konsepkonsep dan aturan-aturan harus sintesis menjadi bentuk-bentuk kompleks yang baru agar siswa dapat menghadapi situasi-situasi masalah yang baru, jadi pemecahan masalah adalah kemampuan peserta didik untuk menyelesaikan pertnyaan yang menantang yang tidak dapat dipecahkan oleh prosedur rutin yang sudah diketahui peserta didik.

\section{Kesimpulan}

Berdasarkan hasil penelitian dan pembahasan yang dilakukan maka disimpulkan sebagai berikut:

1. Pemecahan masalah siswa subjek kemampuan tinggi gender perempuan (SKTGP) subjek kemampuan tinggi gender laki-laki (SKTGL) dalam menyelesaikan soal bangun datar persegi yaitu : (a) memahami masalah, ditunjukkan subjek melakukan 
identifikasi dari soal dengan menuliskan informasi yang ditemukan berupa yang diketahui seperti panjang sisi yang diketahui, dan ditanyakan yang lain serta membuat catatan penting berupa cakaran untuk mempermudah subjek dalam menyelesaikan soal. (b) merencanakan masalah ditunjukkan subjek menggunakan informasi yang diketahui berupa panjang sisi untuk membuat informasi yang baru dalam memudahkan subjek menyelesaikan soal persegi. (c) melakukan rencana pemecahan, ditunjukkan dengan menggunakan rumus sederhana terlebih dahulu selanjutnya subjek melihat kembali apa yang diketahui serta subjek membuat cara penyelesaiannya. (d) melihat kembali, ditunjukkan dengan melihat kembali apa perintah dari soal yang diberikan serta cara penyelesaiannya sehingga subjek dapat menarik kesimpulan dari jawaban yang didapatkan.

2. Pemecahan masalah siswa subjek kemampuan tinggi gender perempuan (SKTGP) subjek kemampuan tinggi gender laki-laki (SKTGL) dalam menyelesaikan soal bangun datar segitiga yaitu: (a) memahami masalah, ditunjukkan subjek melakukan identifikasi dari soal dengan menuliskan informasi yang ditemukan berupa yang diketahui seperti sudut-sudut segitiga, dan ditanyakan besar sudut yang lain serta membuat catatan penting berupa cakaran untuk mempermudah subjek dalam menyelesaikan soal segitiga. (b) merencanakan masalah ditunjukkan subjek menggunakan informasi yang diketahui berupa sudut-sudut segitiga untuk membuat informasi yang baru dalam memudahkan subjek menyelesaikan soal segitiga. (c) melakukan rencana pemecahan, ditunjukkan dengan menggunakan rumus sederhana terlebih dahulu selanjutnya subjek melihat kembali apa yang diketahui seperti sudut-sudut segitiga dan ditanyakan besar sudut yang lain serta subjek membuat cara penyelesaiannya. (d) melihat kembali, ditunjukkan dengan melihat kembali apa perintah dari soal yang diberikan serta cara penyelesaiannya sehingga subjek dapat menarik kesimpulan dari jawaban yang didapatkan.

3. Pemecahan masalah siswa subjek kemampuan tinggi gender perempuan (SKTGP) subjek kemampuan tinggi gender laki-laki (SKTGL) dalam menyelesaikan soal bangun datar segiempat yaitu: (a) memahami masalah, ditunjukkan subjek menyelesaikan soal dengan menuliskan informasi yang ditemukan dari soal berupa 
yang diketahui seperti keliling denah kemudian panjang dan lebar dari segiempat serta yang ditanyakan nilai $\mathrm{x}$ dari panjang dan lebar segiempat serta membuat catatan penting berupa cakaran untuk mempermudah subjek dalam menyelesaikan soal segiempat. (b) merencanakan masalah, ditunjukkan subjek menggunakan informasi yang diketahui berupa keliling denah kemudian panjang dan lebar dari segiempat untuk membuat informasi yang baru untuk mencari nilai $\mathrm{x}$ dengan menggunakan rumus keliling. (c) melakukan rencana pemecahan, ditunjukkan subjek dengan mensubstitusi semua yang diketahui kedalam rumus keliling. (d) melihat kembali, ditunjukkan dengan melihat kembali apa yang diketahui berupa keliling denah kemudian panjang dan lebar dari segiempat dan ditanyakan nilai $\mathrm{x}$ dari panjang dan lebar segiempat serta cara penyelesaiannya sehingga subjek dapat menarik kesimpulan dari jawaban yang telah diperoleh.

\section{Daftar Pustaka}

Hoang, T. N. 2008 “The Effects Of Grade Level, Gender and Ethnicity On Attitude and Learning Exprerimences of Girls and Boys". ISSN : Journal of Research on Technology in education / volume 41 Issue 3 Hal : 253 - 276

National Council Of Teachers Of Mathematic (NCTM). 2000. Priciple and Standarts For School Mathematics. NCTM.

Sumarmo. 2005. Suatu Alternatif Pengajaran Untuk Meningkatkan Pemecahan Masalah Matematika pada Guru dan Siswa SMA. Laporan Hasil Penelitian FMIPA IKIP Bandung. Bandung.

Wulandari. (2016). Eksperimentasi Model Pembelajaran Survey, Question, Read, Recite, Review (SQ3R) dan SQ4R ditinjau dari Jenis Kelamin dan Gaya Kognitif. Jurnal Elektronik Pembelajaran Matematika, 4(1), 34-47

Yosepa, R. 2001. Diagnosis Kesalahan Siswa Dalam Menyelesaikan Soal Matematika Berdasarkan Teori G. Polya. Skripsi tidak diterbitkan. Bandung: FMIPA Universitas Pendidikan Indonesia. 